\title{
Teaching Cell Biology in Primary Schools
}

\author{
Francele de Abreu Carlan, ${ }^{1}$ Lenira Maria Nunes Sepel, ${ }^{1,2}$ and Elgion Lucio Silva Loreto ${ }^{1,3}$ \\ ${ }^{1}$ PPG Educação em Ciências Química da Vida e Saúde, Universidade Federal de Santa Maria, Predio 13-C, Campus Camobi, \\ 7105-970 Santa Maria, RS, Brazil \\ ${ }^{2}$ Departamento de Biologia e PPG Educação em Ciências Química da Vida e Saúde, Universidade Federal de Santa Maria, \\ Predio 16-B, Campus Camobi, 97105-970 Santa Maria, RS, Brazil \\ ${ }^{3}$ Departamento de Bioquimica e Biologia Molecular e PPG Educação em Ciências Química da Vida e Saúde, \\ Universidade Federal de Santa Maria, Predio 13, Campus Camobi, 97105-970 Santa Maria, RS, Brazil
}

Correspondence should be addressed to Elgion Lucio Silva Loreto; elgion@base.ufsm.br

Received 30 June 2014; Revised 2 November 2014; Accepted 13 November 2014; Published 20 November 2014

Academic Editor: John C. K. Lee

Copyright (C) 2014 Francele de Abreu Carlan et al. This is an open access article distributed under the Creative Commons Attribution License, which permits unrestricted use, distribution, and reproduction in any medium, provided the original work is properly cited.

\begin{abstract}
Basic concepts of cell biology are essential for scientific literacy. However, because many aspects of cell theory and cell functioning are quite abstract, students experience difficulties understanding them. In this study, we investigated whether diverse teaching resources such as the use of replicas of Leeuwenhoek's microscope, visualization of cells using an optical microscope, construction of three-dimensional cell models, and reading of a comic book about cells could mitigate the difficulties encountered when teaching cell biology to 8th-grade primary school students. The results suggest that these didactic activities improve students' ability to learn concrete concepts about cell biology, such as the composition of living beings, growth, and cicatrization. Also, the development of skills was observed, as, for example, the notion of cell size. However, no significant improvements were observed in students' ability to learn about abstract topics, such as the structures of subcellular organelles and their functions. These results suggest that many students in this age have not yet concluded Piaget's concrete operational stage, indicating that the concepts required for the significant learning of abstract subjects need to be explored more thoroughly in the process of designing programs that introduce primary school students to cell biology.
\end{abstract}

\section{Introduction}

Cell theory is a unifying concept in all domains of biology. The idea that all living beings are formed of one or more cells and that all new cells develop from preexisting ones completely changed the way humans understood the living world, its constitution, and its functioning. Although the cells were first described by Robert Hooke in 1665, understanding that cells are the morphological and functional unit of living things took 200 years to be achieved. The cell theory was only developed between 1840 and 1855 by Theodor Schwann, Matthias Schleiden, Robert Remak, and Rudolf Virchow [1]. Furthermore, the extraordinary growth of knowledge in molecular and cellular biology over the past decade has made a basic comprehension of cell biology fundamental to scientific literacy. The central concepts of cell biology allow us to manage available information effectively and to make better decisions in our everyday life as regards health, disease prevention and treatment, nutrition, and reproduction. These notions also permit a broader understanding of the world and the ecological relationship between life forms and their roles in nature.

Considering the importance of these basic biological concepts, teaching cell biology in elementary schools is a necessary task but also a great challenge. Students in both elementary and high school classrooms experience difficulty in understanding basic knowledge about cells. Even after students have completed mandatory levels of schooling, their knowledge remains fragmentary and inadequately integrated on the level of cells and organisms [2-4]. The concepts of cell biology are abstract, and the structures involved are microscopic, which creates an obstacle in the process of effective 
learning. For example, using their senses, students cannot directly perceive metabolic, biochemical, or biophysical processes. These abstract subjects are typically taught in lecture classes, where students are required to memorize information for the purpose of examinations. In many cases, specific declarative knowledge is satisfactory for the usual evaluation process at school. However, difficulties arise when students are asked to explain the functional relation between cellular processes and the functions of more complex multicellular organisms $[5,6]$. If the questions posed require students to associate concepts or apply them to new situations, the students often do not perform as well.

The astonishing developments in molecular and cellular biology over the past decade have led to a crisis of "how much to teach" in schools [5]. The great amount of content to be covered brings as solution the anticipation of some topics for the elementary school. Consequently, the curriculum of elementary schools is now replete with concepts that were previously addressed in high schools. In the case of cell biology, for example, subcellular structures and the physiological cellular process described in molecular approaches to biology are currently taught in elementary schools [5]. However, to be applicable at this stage of education, these deeply abstract contents need be appropriately translated to a language accessible to the students. In his classical studies on cognitive development, Piaget showed that primary school students below the approximate age of 11-12 years have not yet well developed a capacity for abstract thought. In this phase, which Piaget called the "concrete operational stage of cognitive development" [7], teaching activities need to be focused on concrete propositions. In cell biology, the use of three-dimensional cell models provides a good example of such a concrete learning activity. Similarly, in laboratory activities, the observation of cells and tissues using a microscope allows young students to approach science concretely. However, some authors have manifested criticism to Piaget theory questioning the existence of the stages. Others claim that Piaget theory underestimated children's abilities [8]. According to these critics, children can use different pathways to develop their skills, reaching them in your own time. As consequence, for some educators, with appropriated material/activities, even abstracts concepts could be learned, for all, in every age [9].

In devising learning activities for elementary school students, the active engagement of the students and the possibility of associating funny moments with the learning process are also considered important [10]. Stories, comic books, games, and theater can be used to create lessons that engage students actively. Many studies have compared traditional classes, which are based on the model of "lecturethen-test," and nontraditional classes, which use innovative approaches to encourage students' active engagement; these studies suggest that untraditional class structures are more effective for scientific education. Moreover, additional studies have shown the positive effect of this type of class in the teaching of cell biology [11-13].

Another important aspect of science education lies in students' preexisting knowledge about the subjects under study. Ausubel's cognitive-learning theory contends that the most significant factor in the learning process is what the student already knows $[14,15]$. For significant learning to occur, it is necessary that new concepts have signification in relation to the concepts already familiar to students. In contrast, abstract concepts that are unanchored to preexisting concepts can be memorized but lack adequate signification.

In Brazil, where this study was conducted, there is no minimum curriculum listing the topics to work on basic education. The educational laws provide only general goals to be achieved. In practice, the curriculums that are implemented in the classrooms are those presented by textbooks, distributed by the government, for public schools. For cell biology, the textbooks highlight the subcellular structures and the teachers tend to prioritize these contents in their classes [4]. Since these issues are very abstract, we hypothesized that the use of practical activities as observation of cell and construction of three-dimensional model could mitigate the problems associated with learning these abstract topics.

1.1. Objectives. Some authors have suggested that didactic propositions funny and actives are effective in science education [10-13] and others that even abstract concepts can be teaching to children with age predicted to be in the Piaget's "concrete operational stage of cognitive development" $[7,8]$. On the other side, Ausubel predicts that, for significant learning to occur, the new concepts need be related with preexisting ones $[14,15]$. Growth and cicatrization are concepts known by students. Are these concepts facilitators for learning of basic aspects of cell theory?

To address the mentioned points we designed this study with the following main objectives:

(1) to test whether concrete activities such as the construction of three-dimensional cellular models, observation of cells under a microscope, and/or engagement and integrating humor into the learning process can aid in teaching abstract topics, such as the subcellular components of cells;

(2) to compare the learning of themes that are more close to the reality of students with those that are more abstract, for example, compare if the relationship between cell multiplication and growth or cicatrization is more easily learned than abstract themes, as the subcellular components of cell.

\section{Material and Methods}

2.1. Study Participants. This research was performed on three 8th-grade classes at a public primary school in Santa Maria, RS, Brazil. A total of 65 students of both genders, all of whom were between 12 and 13 years of age, were sampled.

\subsection{Experimental Design}

(1) One class, here called the control class, received "classic" biology instruction about cells by way of lectures and with the aid of a textbook.

(2) The second class, here called the CB (comic book) class, was taught about cell biology using a comic book. The story in the selected $\mathrm{CB}$ addresses aspects of 
cell discovery and cellular processes, such as reproduction and its relationship with growth. Subcellular structures are presented as characters in the comic book who explain their functions in the cell. We wrote the story in simple, direct language. This comic book, which is entitled "The Cell's Guys," can be found (in Portuguese) at the following address: http://w3.ufsm.br/ppgecqv/Producao/turma.pdf.

(3) The third class, here called the DR (diverse resources) class, was instructed using a variety of methods. These included (i) using a replica of the Leeuwenhoek's microscope to understand the history of cell discovery; (ii) observing cells with an optical microscope; (iii) reading the comic book described above; and (iv) constructing a three-dimensional comestible cell.

The process of discovering the microscopic world of cells was emphasized by using a replica of Leeuwenhoek's microscope to examine onion cells [16]. While using the replica, the students were also told about the history and importance of cell discovery. Next, the students observed onion cells with a modern optical microscope. A wet mount slide of onion skin epidermal cells, stained with methylene blue, was used. It was possible comparing this experience seeing the same type of cells using Leeuwenhoek's microscope replica. Students were told that each minuscule cell contains many tiny structures. The subcellular structures were presented using the comic book previously mentioned. Finally, the students created a comestible cell using a "candies kit." This kit contained waffles, candies of different shapes, sizes, and colors, chocolate cream, and a plastic dish. Using the information available in the comic book, the students made a cell model and were asked to describe the structures and to explain their functions. At the end of activity, the cells were "devoured."

To assess whether these activities improved the learning of cell biology, students completed pre- and posttests; the results of these tests were subsequently compared [17]. The posttests were performed two weeks after the last teaching activities. The questions on the tests were objective and were shown to the students using a PowerPoint presentation; for each question, the students were asked to select one of five response options. The students marked their chosen answers on sheets of paper. Four test questions focused on broader aspects of the cell theory and on properties that are more easily recognizable by the student: growth, cicatrization, and the composition of a living being. The average scores of the three classes on the pre- and posttest questions were compared using analysis of variance (ANOVA).

These questions were as follows. (1) What happens when you cut your finger? (2) Can you identify two foods that are composed of cells? (3) Why do we grow up? (4) Can you Identify beings formed by cells?

Another set of four questions was asked on the posttest only. These questions focused on subcellular structures, their forms, and their functions. As with the previous questions, five response options were provided. These questions were asked only in the posttest, as a previously conducted pilot test revealed that few 8 th-grade students had prior knowledge

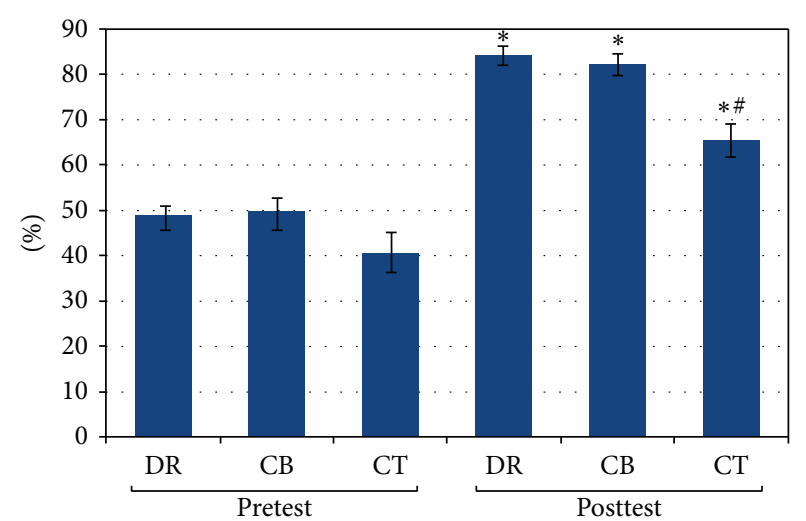

FIgURE 1: Percentage of correct answers for different classes on the pre- and posttest, which included questions about general aspects of cell theory. Black bars represent the standard deviation. DR = class taught using diverse didactic resources; $\mathrm{CB}=$ class taught using the comic book "The Cell's Guys"; CT = control class taught using a "classical" method of biological instruction. * Statistical significance at the 5\% level as determined through ANOVA-based comparisons of each class's pre- and posttest scores. \# represents statistical significance at the $5 \%$ level as determined through ANOVA-based comparisons of different didactic resources.

of subcellular compounds. The average scores of the three groups were compared using a $t$-test. These questions were as follows. (1) Which items in the figure represent the mitochondria and the Golgi apparatus? (2) What is the function of lysosome? (3) What does the structure indicated by the arrow do (endoplasmic reticulum)? (4) Which structure or structures are the most important for cell functioning?

For the CB and DR classes, an open-ended question was asked about students' perceptions of the conducted activities.

\section{Results and Discussion}

All three classes showed significant improvement on the posttest in answering the first group of questions, which concerned general aspects of cell biology and had links to the biological phenomena that students experience everyday (e.g., growth, cicatrization, and constitution of foods) (Figure 1). Prior to the lessons, 40 to $50 \%$ of students were able to answer the questions correctly. Although all teaching strategies led to improvement in these scores, the use of diverse didactic resources, as well as the use of the comic book alone, resulted in greater improvement than that achieved through "classical" instruction. While the control class scored approximately $65 \%$ on the posttest, the CB and DR classes scored approximately $80 \%$.

These results suggest that the relationships between (1) cells and growth and (2) cell division and cicatrization are easily grasped by students. The same can be inferred to cell as constituent of living beings. As Piaget suggests, students in early adolescence, including those studied in this research, have not yet fully developed the capacity for abstract thought Instead, these students learn more easily what they can concretely observe. However, the students have previously 


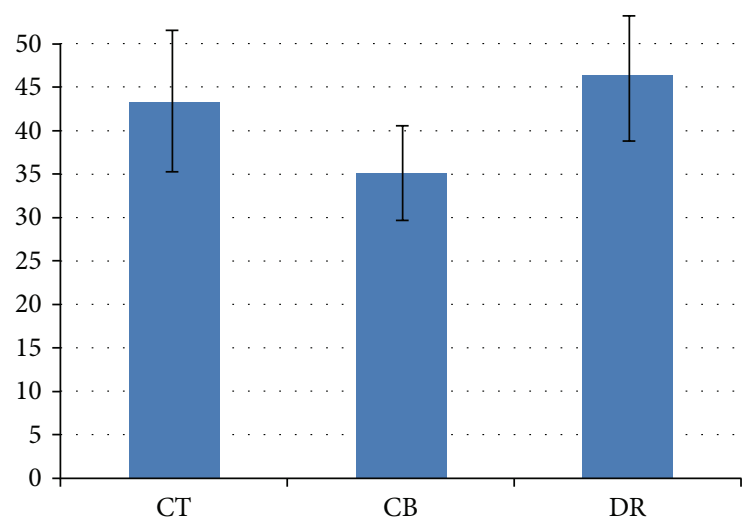

FIGURE 2: Average percentage of correct answers for questions about the subcellular compounds of cells. Black bars represent the standard deviation. $\mathrm{DR}=$ class taught using diverse didactic resources; $\mathrm{CB}=$ class taught using the comic book "The Cell's Guys"; CT = control class taught using a "classical" method of biological instruction. The averages were compared using a $t$-test. No statistically significant differences were observed.

learned to discern between living and nonliving beings, and they have learned about growth and cicatrization. As Ausubel [15] has shown, the existence of concepts in the students' minds that can be linked to new concepts permits significant learning.

No significant differences were observed between the $\mathrm{CB}$ and DR classes. As the topics focused in these questions were treated in the $\mathrm{CB}$, while quickly, appears is enough for teaching these subjects. The weaker performance observed in the control class suggests that the relationships between cells and biological phenomena such as growth and cicatrization were not covered adequately in that class.

For questions about the subcellular compounds of cells and their functions, no differences were observed between the students in the DR, CB, and control classes (Figure 2). Even those students who created a three-dimensional cell model did not show improvement in learning about subcellular organelles. On average, students in all classes scored approximately $40-45 \%$ on the posttest questions related to subcellular compounds. One possible explanation for these low scores is that the subject of subcellular compounds involves "invisible," abstract structures. As noted previously, students in early adolescence have not yet developed the capacity to think abstractly [7].

It is possible that other strategies may allow primary school students to learn about cell organelles more effectively. For instance, learning efficacy might be increased if diverse didactic resources were used throughout the instruction period instead of during select periods of instruction. It is also possible that homework assignments might have resulted in increased scores on the posttest. However, our study suggests that even using didactic resources varied the learning of the abstract topic as subcellular organelles are very low at this stage of education. In addition to being a very abstract theme, the students probably do not understand the necessary concepts to link with these new ones and provide them with significance [15].
The students' responses to the open-ended question showed that they did not regard reading the comic book as a pleasurable activity. Otherwise, students described the activities performed in the DR class as very motivating and fun. The activities performed in the DR class were so popular that students in the $\mathrm{CB}$ and control classes subsequently asked the researchers whether they themselves could participate in the microscope and comestible cell activities. In response to the students' request, these activities were carried out in the $\mathrm{CB}$ and control classes after the posttest. However, despite the popularity of these activities among the students, they did not prove as effective as expected in teaching the students about cell organelles.

\section{Conclusions}

(i) 8th-grade primary school students easily learn those topics of cell biology that are closely related to their everyday reality, including cell division and growth, or cicatrization, and the composition of living beings, as predict by Piaget's theory and, also, by Ausubel theory.

(ii) Teaching activities that actively engage students, such as the use of microscopes, the building of threedimensional cells, or the reading of comic books about cellular topics, improve students' ability to learn about these concrete concepts.

(iii) Even using diverse didactic resources, abstract concepts, such as the structures and functions of subcellular organelles, are difficult to teach in primary schools, as predict by Piaget's theory.

(iv) Humorous activities can greatly motivate students but do not necessarily improve the learning of abstract topics.

\section{Conflict of Interests}

The authors declare that there is no conflict of interests regarding the publication of this paper.

\section{Acknowledgments}

The authors would like to thank Conselho Nacional de Desenvolvimento Científico e Tecnológico (CNPq) and Coordenação de Aperfeiçoamento de Pessoal de Nível Superior (CAPES/Rede Nacional de Educação e Ciência) for grants and fellowships.

\section{References}

[1] P. Mazzarello, "A unifying concept: the history of cell theory," Nature Cell Biology, vol. 1, no. 1, pp. e13-e15, 1999.

[2] A. Dreyfus and E. Jungwirth, "The pupil and the living cell; a taxonomy of dysfunctional ideas about an abstract idea," Journal of Biological Education, vol. 23, no. 1, pp. 49-55, 1989.

[3] R. P. Verhoeff, Towards Systems Thinking in Cell Biology Education, Coeur d'Alene Press, Utrecht, The Netherlands, 2003. 
[4] F. A. Carlan, L. M. N. Sepel, and E. L. S. Loreto, "Explorando diferentes recursos didáticos no ensino fundamental: uma proposta para o ensino de célula," Revista Acta Scientiae, vol. 15, pp. 323-338, 2013.

[5] S. E. DiCarlo, "Cell biology should be taught as science is practised," Nature Reviews Molecular Cell Biology, vol. 7, no. 4, pp. 290-296, 2006.

[6] M. R. L. Palmero and M. A. Moreira, "Modelos mentales de la estructura y el funcionamiento de La célula: dos estudios de casos," Investigações em Ensino de Ciências, vol. 4, no. 2, pp. 121$160,1999$.

[7] H. P. Ginsburg and S. Opper, Piaget's Theory of Intellectual Development, Prentice Hall, Upper Saddle River, NJ, USA, 1987.

[8] R. Driver, "When is a stage not a stage? A critique of Piaget's theory of cognitive development and its application to science education," Educational Research, vol. 21, no. 1, pp. 54-61, 1978.

[9] O. Lourenço and A. Machado, "In defense of piaget's theory: a reply to 10 common criticisms," Psychological Review, vol. 103, no. 1, pp. 143-164, 1996.

[10] G. Davies, "Stories, fun and games: teaching genetics in primary school," Journal of Biological Education, vol. 40, no. 1, p. 31, 2005.

[11] C. N. Spiegel, G. G. Alves, T. D. S. Cardona et al., "Discovering the cell: an educational game about cell and molecular biology," Journal of Biological Education, vol. 43, no. 1, pp. 27-35, 2008.

[12] A. Lewis, M. Peat, and S. Franklin, "Understanding protein synthesis: an interactive card game discussion," Journal of Biological Education, vol. 39, no. 3, pp. 125-129, 2005.

[13] K. S. A. Cabello, L. Rocque, and I. C. F. de la Sousa, "Uma história em quadrinhos para o ensino e divulgação da hanseníase," Revista Electrónica de Enseñanza de las Ciencas, vol. 9, no. 1, pp. 225-241, 2010.

[14] D. P. Ausubel, Educational Psychology: A Cognitive View, Holt, Rinehart \& Winston, New York, NY, USA, 1968.

[15] D. P. Ausubel, The Acquisition and Retention of Knowledge: A Cognitive View, Kluwer Academic Publishers, Dordrecht, The Netherlands, 2000.

[16] L. M. N. Sepel, E. L. S. Loreto, and J. B. T. Rocha, "Using a replica of Leeuwenhoek's microscope to teach the history of science and to motivate students to discover the vision and the contributions of the first microscopists," CBE Life Sciences Education, vol. 8, no. 4, pp. 338-343, 2009.

[17] M. D. Sundberg, "Assessing student learning," Cell Biology Education, vol. 1, no. 1-2, pp. 11-15, 2002. 

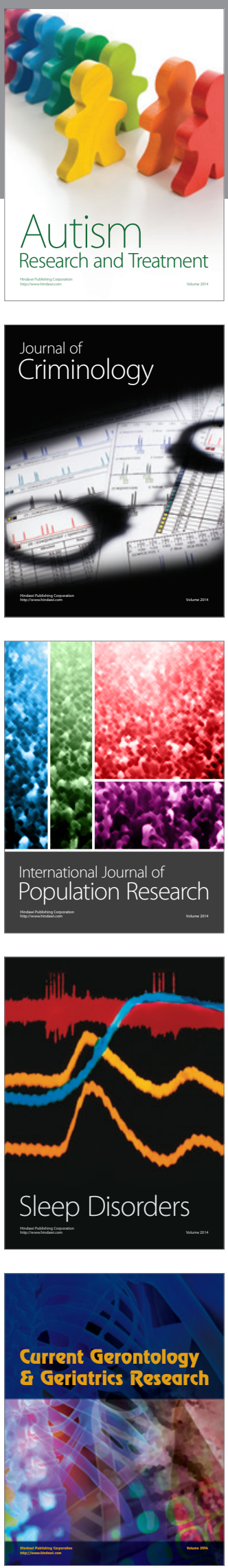
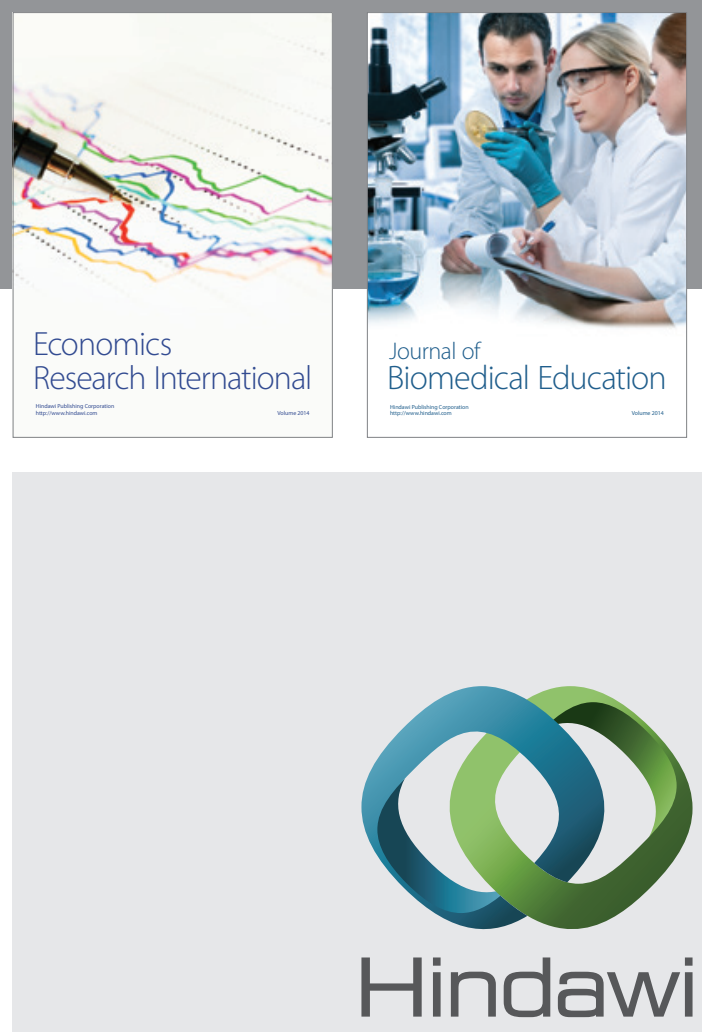

Submit your manuscripts at

http://www.hindawi.com
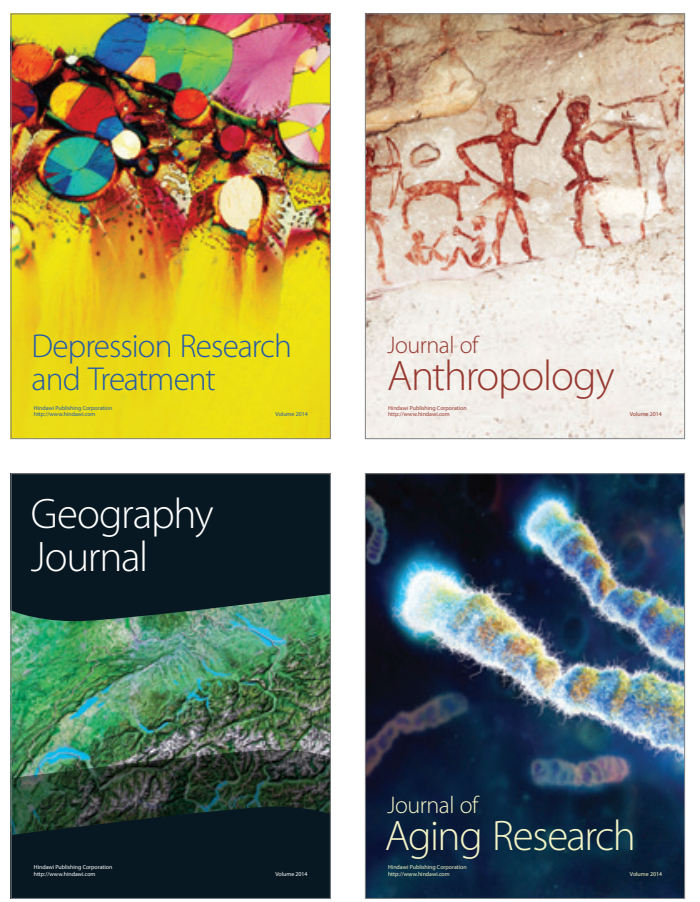
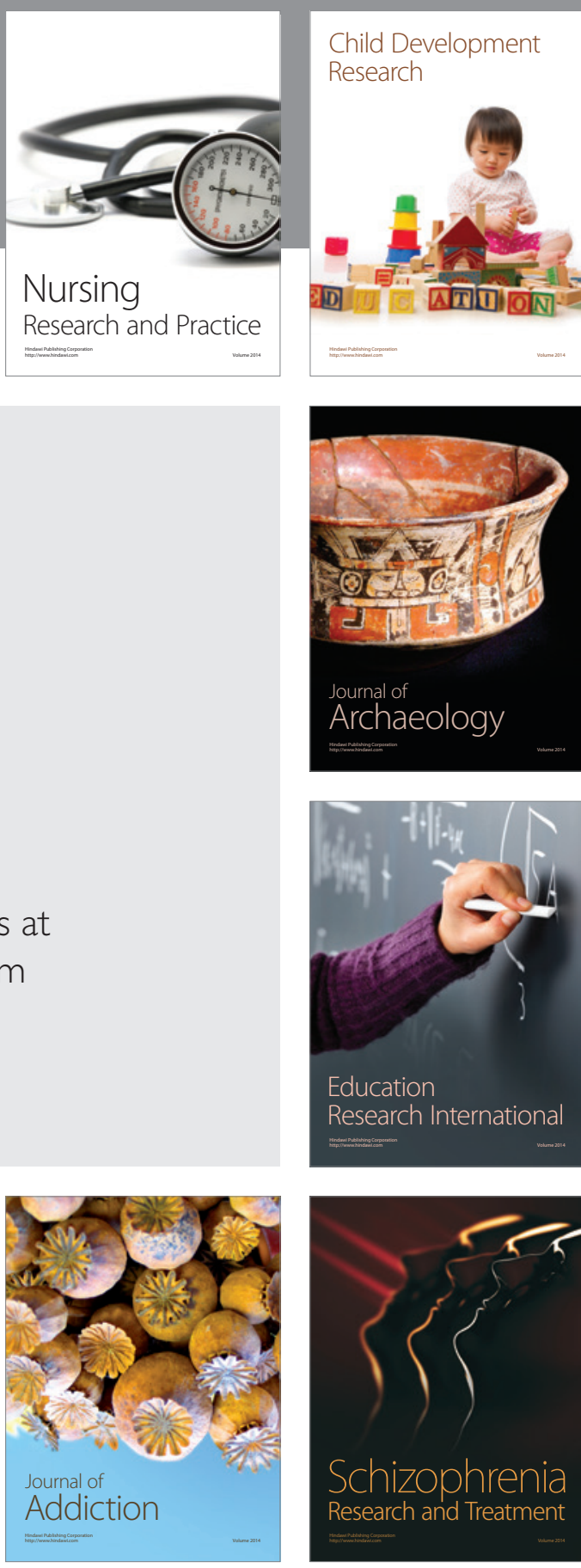

(D)
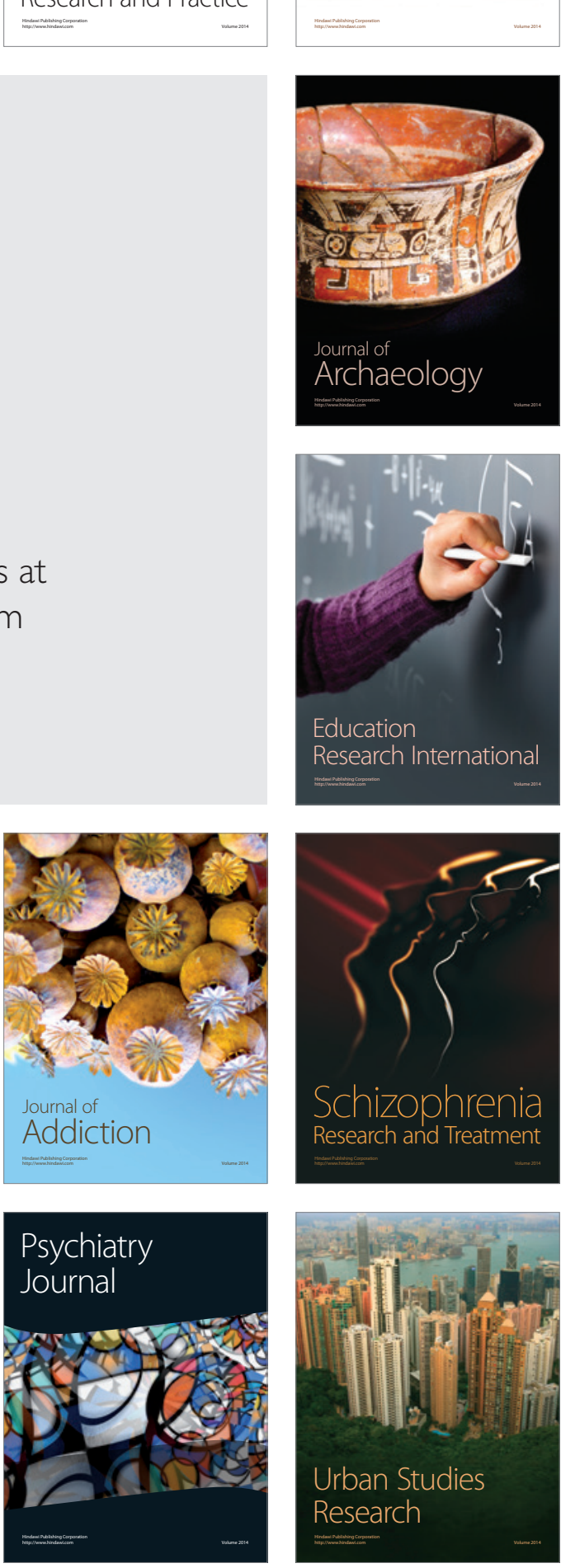